\title{
Comparison of adiposity measures in the identification of adolescents with hypertension
}

\author{
Swastika Roy ${ }^{1}$, *Jyoti Ratan Ghosh ${ }^{2}$ \\ Sri Lanka Journal of Child Health, 2019; 48(1): 39-46
}

\begin{abstract}
Background: Hypertension in children is becoming a growing heath problem, with increasing prevalence.
\end{abstract}

Objectives: To examine the relationship of body mass index (BMI), waist circumference (WC), waist hip ratio (WHR), waist stature ratio (WSR) and conicity index (CI) with blood pressure and to differentiate the screening potential of BMI, WC, WHR, WSR and CI for the presence of hypertension in children.

Method: A school-based cross-sectional study was carried out in 2017 on 13-16 year old Bengali children in two schools (a boys' school and a girl's school) from Howrah city, West Bengal where stature (ST), weight (WT), WC and hip circumference (HC) were measured, and BMI, WHR, WSR and CI calculated. Schools were randomly selected from the list of affiliated schools under the West Bengal Board of Secondary Education. All 13-16 year old children from the two schools were recruited after obtaining informed consent from parents and assent from the children. Children with pre-existing serious illnesses and deformities were excluded from the study. Bio-social information was obtained using an open-ended schedule. Age was obtained from the school register. Hypertension was defined as age and stature adjusted systolic blood pressure (SBP) and/or diastolic blood pressure $(\mathrm{DBP}) \geq 95^{\text {th }}$ percentile. Partial correlations, logistic regressions and area under the receiver operating characteristic curves (AUC) were estimated to understand the relationship of adiposity measure with blood pressure and hypertension.

${ }^{1}$ Research Scholar, ${ }^{2}$ Assistant Professor,
Department of Anthropology, Visva-Bharati
University, West Bengal, India
${ }^{*}$ Correspondence: jrghosh@rediffmail.com
(Received on 24 April 2018: Accepted after
revision on 29 June 2018)
The authors declare that there are no conflicts of
interest
Funding: Research scholar is getting UGC fellowship
from Visva-Bharati, Govt. of India
Open Access Article published under the Creative

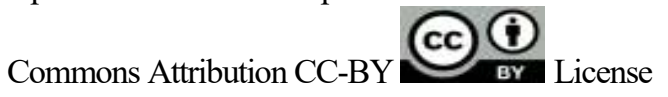

Results: A total of 535 adolescents, comprising 282 boys and 253 girls aged 13-16 years, participated in this study. There was no statistically significant sex difference in age. Overall prevalence of hypertension was $8.5 \%$. All adiposity measures were positively correlated with blood pressures. Logistic regression showed that BMI had the strongest associations with hypertension in both sexes. The AUC for BMI $(0.82,95 \%$ CI 0.751 to 0.895$)$ was higher than those of other adiposity measures in assessing hypertension in boys. However, in girls, both BMI (AUC $0.75,95 \%$ CI 0.644 to 0.856 ) and WSR (AUC $0.75,95 \%$ CI 0.638 to 0.865 ) had similar higher assessment ability for hypertension compares to other measures.

Conclusions: BMI had the highest odds ratio for hypertension, and was the best adiposity measure to assess hypertension.

DOI: http://dx.doi.org/10.4038/sljch.v48i1.8650

(Keywords: Adolescents, body mass index, adiposity, hypertension)

\section{Introduction}

Today, in developing countries, there is a marked shift from communicable to non-communicable diseases ${ }^{1}$. Studies show a high prevalence of obesity among children globally ${ }^{2}$. Obesity is the most significant risk factor for childhood hypertension ${ }^{3,4}$. Obese children have a threefold greater risk for high blood pressure compared to non-obese children ${ }^{5}$. Hypertension is identified as the third major risk factor of deaths among children, and the prevalence of hypertension in children is increasing ${ }^{6}$. Moreover, among children, especially those with obesity, hypertension is associated with end-organ damage ${ }^{7,8}$. However, little attention has been paid to the problem of hypertension in the young. Increasing evidence suggests blood pressure tracking from childhood to adulthood ${ }^{9}$. High blood pressure in children is associated with increased cardiac morbidity and mortality ${ }^{10}$. However, remarkably, the prevalence of hypertension in children is generally underestimated $^{8}$. Body fat distribution, rather than the extent of obesity, determines the hypertension risk $^{11}$. Rational assessment of body fat distribution involves measurement of body mass index (BMI), waist circumference (WC) and waist hip ratio 
$(\mathrm{WHR})^{3,11,12}$. However, there is little data on the relationship between body fat distribution and the risk of high blood pressure in Indian children. Studies that examined the relationships between adiposity measures and hypertension have yielded different findings $s^{7,13}$ and thus, the relationships are not fully understood.

\section{Objectives}

To examine the relationship of BMI, WC, WHR, waist stature ratio (WSR) and conicity index (CI) with blood pressure and to differentiate the screening potential of BMI, WC, WHR, WSR and $\mathrm{CI}$ for the presence of hypertension in Indian children.

\section{Method}

A school-based cross-sectional study was carried out in 2017 on 13-16 year old Bengali children in two schools (a boys' school and a girl's school) from Howrah city, an urban area adjacent to Kolkata, the capital of the state West Bengal. Schools were randomly selected from the list of affiliated schools under the West Bengal Board of Secondary Education. All 13-16 year old children from the two schools were recruited after obtaining informed consent from parents, permission from the schools and assent from the children. Children with pre-existing serious illnesses and deformities were excluded from the study. Bio-social information was obtained using an open-ended schedule. Age was obtained from the school register. Ethical clearance for the study was obtained from the Research Board, Visva-Bharati University, West Bengal, India.

Children enrolled in study were physically examined to obtain stature (ST), weight (WT), WC and hip circumference (HC) in accordance with standard guidelines ${ }^{14}$. ST was measured to the nearest $0.1 \mathrm{~cm}$ using an anthropometer. WT was measured in light clothing without shoes to the nearest $0.1 \mathrm{~kg}$ using an electronic scale. WC and
$\mathrm{HC}$ were measured to the nearest $0.1 \mathrm{~cm}$ in standing position using a non-elastic flexible tape. BMI [WT $(\mathrm{kg}) / \mathrm{ST}\left(\mathrm{m}^{2}\right)$ ], WHR [WC $(\mathrm{cm}) / \mathrm{HC}$ $(\mathrm{cm})]$, WSR $[\mathrm{WC}(\mathrm{cm}) / \mathrm{ST}(\mathrm{cm})]$ and $\mathrm{CI}=\mathrm{WC}(\mathrm{m}) /$ $\{0.109 \times \sqrt{ }[\mathrm{WT}(\mathrm{kg}) / \mathrm{HT}(\mathrm{m})]\}$ were calculated subsequently.

Systolic blood pressure (SBP) and diastolic blood pressure (DBP) in left arms were measured in each student using a sphygmomanometer with appropriate cuff. Each student was requested to sit quietly for 5 minutes before taking the blood pressure to relieve any stress. The mean of two measurements was taken. Hypertension was defined as age and ST adjusted SBP and/or DBP $\geq 95^{\text {th }}$ percentile ${ }^{15}$.

Descriptive statistics were computed by sex for age, anthropometric variables and blood pressures, and expressed as mean and standard deviation (SD). Student-t test was used to compare anthropometric and blood pressure variables between boys and girls. Partial correlations, adjusted for age and ST were estimated separately for both sexes to examine association of adiposity measures with blood pressures. Logistic regressions adjusted for age and ST were used to examine relationship of adiposity measures with hypertension. The area under each receiver operating characteristic curves (AUC) and 95\% confidence intervals $(95 \% \mathrm{CI})$ were estimated to understand the relative ability of various adiposity measures to assess hypertension. Statistical analysis was conducted with software package IBM SPSS (version 22.0). A $p$ value less than 0.05 was considered of significance.

\section{Results}

A total of 535 apparently healthy adolescents comprising 282 boys and 253 girls were included in the study. Characteristics of the studied population are presented in Table 1 .

Table 1: Characteristics of the studied population

\begin{tabular}{|l|c|c|c|c|c|}
\hline \multirow{2}{*}{ Variable } & \multicolumn{2}{|c|}{ Boys } & \multicolumn{2}{c|}{ Girls } & \multirow{2}{*}{$\boldsymbol{p}$} \\
\cline { 2 - 5 } & Mean & SD & Mean & SD & \\
\hline Age (years) & 14.77 & 1.17 & 14.95 & 1.17 & $>0.05$ \\
\hline Stature $(\mathrm{cm})$ & 161.04 & 8.21 & 151.51 & 6.18 & $<0.01$ \\
\hline Weight $(\mathrm{kg})$ & 55.38 & 11.96 & 50.78 & 11.32 & $<0.01$ \\
\hline Waist circumference $(\mathrm{cm})$ & 78.33 & 9.78 & 74.72 & 10.76 & $<0.01$ \\
\hline Hip circumference $(\mathrm{cm})$ & 89.22 & 8.37 & 87.69 & 10.27 & $>0.05$ \\
\hline Body mass index $\left(\mathrm{kg} / \mathrm{m}^{2}\right)$ & 21.26 & 3.91 & 22.06 & 4.44 & $<0.05$ \\
\hline Waist hip ratio $(\mathrm{cm} / \mathrm{cm})$ & 0.87 & 0.04 & 0.85 & 0.04 & $<0.01$ \\
\hline Waist stature ratio $(\mathrm{cm} / \mathrm{cm})$ & 0.48 & 0.05 & 0.49 & 0.06 & $>0.05$ \\
\hline *Conicity index $(\mathrm{CI})$ & 1.23 & 0.05 & 1.18 & 0.08 & $<0.01$ \\
\hline Systolic blood pressure $(\mathrm{mm} \mathrm{Hg})$ & 112.47 & 12.02 & 102.76 & 10.09 & $<0.01$ \\
\hline Diastolic blood pressure $(\mathrm{mm} \mathrm{Hg})$ & 66.31 & 7.97 & 63.40 & 7.29 & $<0.01$ \\
\hline
\end{tabular}

SD: Standard deviation, ${ }^{*} \mathrm{CI}=$ Waist circumference $(\mathrm{m}) /\{0.109 \times \sqrt{ }[$ Weight $(\mathrm{kg}) / \mathrm{Height}(\mathrm{m})]\}$ 
There were no significant sex differences in age, $\mathrm{HC}$ and WSR. However, boys had significantly higher mean values than girls in ST, WT, WC, BMI, WHR, CI, SBP and DBP (Table 1). The prevalence of hypertension in boys and girls was
$8.2 \%$ and $8.7 \%$, respectively with an overall prevalence of $8.5 \%$. Gender wise partial correlation coefficients of SBP and DBP with anthropometric variables are presented in Table 2.

Table 2: Partial correlation between adiposity measures and blood pressure

\begin{tabular}{|l|c|c|c|c|c|c|c|c|}
\hline \multirow{2}{*}{ Variable* } & \multicolumn{4}{|c|}{ Boys } & \multicolumn{4}{c|}{ Girls } \\
\cline { 2 - 9 } & \multicolumn{2}{|c|}{ SBP } & \multicolumn{2}{c|}{ DBP } & \multicolumn{2}{c|}{ SBP } & \multicolumn{2}{c|}{ DBP } \\
\cline { 2 - 9 } & $\mathrm{r}$ & $p$ & $\mathrm{r}$ & $p$ & $\mathrm{r}$ & $p$ & $\mathrm{r}$ & $p$ \\
\hline Body mass index (BMI) & 0.439 & $<0.01$ & 0.352 & $<0.01$ & 0.510 & $<0.01$ & 0.391 & $<0.01$ \\
\hline Waist circumference (WC) & 0.379 & $<0.01$ & 0.306 & $<0.01$ & 0.491 & $<0.01$ & 0.411 & $<0.01$ \\
\hline Waist hip ratio (WHR) & 0.184 & $<0.01$ & 0.140 & $<0.05$ & 0.209 & $<0.01$ & 0.220 & $<0.01$ \\
\hline Waist stature ratio (WSR) & 0.374 & $<0.01$ & 0.306 & $<0.01$ & 0.492 & $<0.01$ & 0.413 & $<0.01$ \\
\hline Conicity index (CI) & 0.108 & $>0.05$ & 0.102 & $>0.05$ & 0.204 & $<0.01$ & 0.241 & $<0.01$ \\
\hline
\end{tabular}

* adjusted for age and stature

SBP: Systolic blood pressure, DBP: Diastolic blood pressure

All correlations were positive and significant $(p<0.05)$, except for CI with SBP and DBP in boys. The age and ST adjusted odds ratio (OR) along with $95 \%$ confidence intervals of BMI, WC, WHR, WSR and CI for hypertension are shown in Table 3.

Table 3: Odds ratios of adiposity measures for hypertension

\begin{tabular}{|c|c|c|c|c|c|c|c|c|}
\hline \multirow[b]{3}{*}{ Variable* } & \multicolumn{4}{|c|}{ Boys } & \multicolumn{4}{|c|}{ Girls } \\
\hline & \multirow[t]{2}{*}{ OR } & \multicolumn{2}{|c|}{$95 \% \mathrm{CI}$} & \multirow[t]{2}{*}{$p$} & \multirow[t]{2}{*}{ OR } & \multicolumn{2}{|c|}{$95 \% \mathrm{CI}$} & \multirow[t]{2}{*}{$p$} \\
\hline & & Lower & Upper & & & Lower & Upper & \\
\hline Body mass index (BMI) & 1.380 & 1.212 & 1.571 & $<0.01$ & 1.220 & 1.100 & 1.353 & $<0.01$ \\
\hline Waist circumference (WC) & 1.129 & 1.071 & 1.190 & $<0.01$ & 1.115 & 1.059 & 1.174 & $<0.01$ \\
\hline Waist hip ratio (WHR) & 1.133 & 1.029 & 1.249 & $<0.01$ & 1.129 & 1.019 & 1.252 & $<0.05$ \\
\hline Waist stature ratio (WSR) & 1.214 & 1.116 & 1.321 & $<0.01$ & 1.176 & 1.089 & 1.270 & $<0.01$ \\
\hline Conicity index (CI) & 1.092 & 1.004 & 1.187 & $<0.05$ & 1.102 & 1.028 & 1.182 & $<0.01$ \\
\hline
\end{tabular}

*Adjusted for age and stature

OR: Odds ratio, 95\% CI: 95\% confidence interval

All anthropometric variables were significantly and positively associated with hypertension (Table 3 ).
The AUC in assessing hypertension for adiposity measures are shown in Table 4.

Table 4: Area under the ROC curves of different adiposity measures in assessing hypertension

\begin{tabular}{|c|c|c|c|c|c|c|c|c|}
\hline \multirow[t]{3}{*}{ Variable* } & \multicolumn{4}{|c|}{ Boys } & \multicolumn{4}{|c|}{ Girls } \\
\hline & \multirow[t]{2}{*}{ AUC } & \multicolumn{2}{|c|}{$95 \% \mathrm{CI}$} & \multirow[t]{2}{*}{$p$} & \multirow[t]{2}{*}{ AUC } & \multicolumn{2}{|c|}{$95 \%$ CI } & \multirow[t]{2}{*}{$p$} \\
\hline & & Lower & Upper & & & Lower & Upper & \\
\hline Body mass index (BMI) & 0.82 & 0.751 & 0.895 & $<0.01$ & 0.75 & 0.644 & 0.856 & $<0.01$ \\
\hline Waist circumference (WC) & 0.80 & 0.707 & 0.884 & $<0.01$ & 0.72 & 0.599 & 0.841 & $<0.01$ \\
\hline Waist hip ratio (WHR) & 0.65 & 0.540 & 0.757 & $<0.05$ & 0.65 & 0.523 & 0.767 & $<0.05$ \\
\hline Waist stature ratio (WSR) & 0.77 & 0.686 & 0.864 & $<0.01$ & 0.75 & 0.638 & 0.865 & $<0.01$ \\
\hline Conicity index (CI) & 0.62 & 0.506 & 0.727 & $>0.05$ & 0.66 & 0.540 & 0.781 & $<0.05$ \\
\hline
\end{tabular}

AUC: Area under each receiver operating characteristic curves, 95\% CI: 95\% confidence interval

Apart from the CI in boys, AUCs of all adiposity measures were significantly higher than the noneffect value 0.5 . The AUC for BMI $(0.82,95 \%$ CI 0.751 to 0.895$)$ was larger than those of other measures in assessing hypertension in boys (Figure 1).
However, in girls, both BMI (AUC 0.75, 95\% CI 0.644 to 0.856 ) and WSR (AUC $0.75,95 \% \mathrm{CI}$ 0.638 to 0.865 ) had similar higher assessment ability for hypertension compared to other measures (Figure 2). 


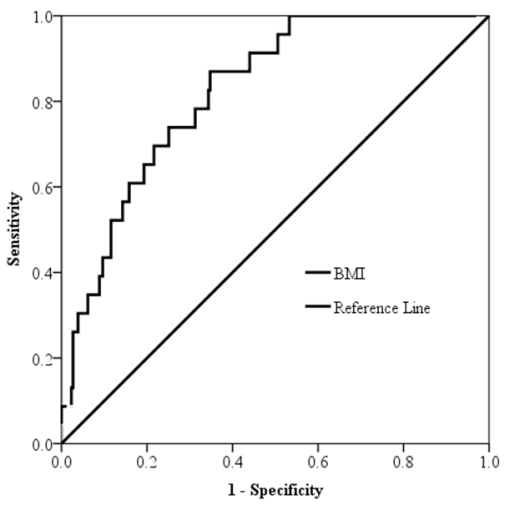

Figure 1: Area under the ROC curves for BMI $\left(\mathrm{kg} / \mathrm{m}^{2}\right)$ in assessing hypertension in boys ROC: Receiver operating characteristic

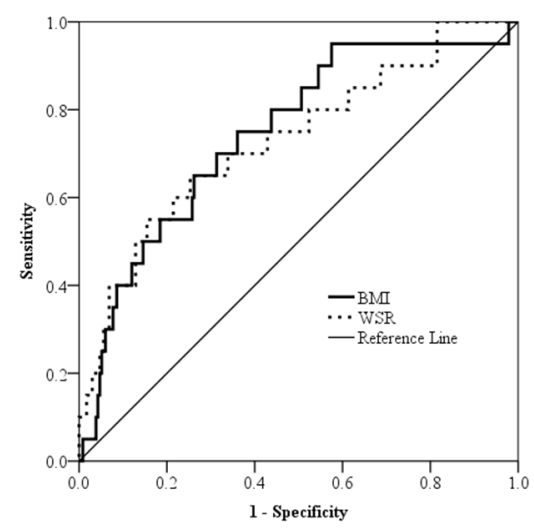

Figure 2: Area under the ROC curves for BMI $\left(\mathrm{kg} / \mathrm{m}^{2}\right)$ and WSR in assessing hypertension in girls

ROC: Receiver operating characteristic

\section{Discussion}

Hypertension in adults is now recognized globally as a major public health problem ${ }^{16}$. Unexpectedly, hypertension in children is also becoming a growing heath problem, with increasing prevalence ${ }^{17}$. Interestingly, the complications of hypertension not only occur in adult patients, but can involve children as well ${ }^{4}$.

This cross sectional study explored the relationship of various adiposity measures with blood pressures in adolescents living in an urban community. In addition, we studied the screening potential of BMI, WC, WHR, WSR and CI for the presence of hypertension. We found that, even though participants were of similar age, males tended to have higher mean anthropometric measurements compared to females, except for BMI and WSR. The prevalence of hypertension in boys and girls was $8.2 \%$ and $8.7 \%$, respectively. Similar to the present study, higher prevalence of hypertension in girls was observed by Nkeh-Chungag et al. ${ }^{8}$.
Durrani et al. also found a higher prevalence of hypertension in girls as compared to boys ${ }^{18}$. Contrary to that, Gamboa-Delgado et al. ${ }^{13}$ observed that prevalence of hypertension was more in boys than in girls ${ }^{13}$. Similar findings were also reported by other studies ${ }^{3}$. However, the overall prevalence of hypertension in the present study was $8.5 \%$ which is higher than in the recently published studies by Hansel et al. ${ }^{19}$ (3.6\%), Patel et al. ${ }^{20}$ $(5.4 \%)$ and Vohra et al. ${ }^{21}(3.1 \%)$. Compared to the present study, a lower prevalence of hypertension was also observed in children of Wardha $(5.75 \%)^{22}$ and Patna $(4.6 \%)^{23}$. However, Durrani and Waseem ${ }^{24}$ reported that $9.4 \%$ of children were hypertensive in their study population.

The results of the present study revealed that all adiposity measures were positively correlated with blood pressures, though the association of CI with SBP and DBP were not significant. Similar positive associations were also observed in recent studies $^{3,23}$. In this study, logistic regression analysis showed a very strong positive association of BMI with risk of hypertension prevalence in these children. Zhang et al. also reported a strong positive association of high blood pressure with BMI in children of Hainan province of China ${ }^{25}$. Similar positive association between hypertension and BMI was also observed by Sun et al. ${ }^{26}$. Some studies reported an association between childhood obesity and hypertension ${ }^{23,27}$. Study also demonstrated that children with hypertension had higher mean BMI compared with the prehypertensive and normal weight participants ${ }^{4}$. Another recent study demonstrated that being in an early onset obese or overweight trajectory was associated with increased risk of childhood hypertension'. Moreover, overweight children had a twofold greater risk of hypertension whilst obese children had a fourfold risk $^{28}$. Other studies also demonstrated that increased BMI was associated with increased blood pressure in children ${ }^{29,30}$. ROC curve analysis in the present study also confirmed that BMI had comparatively better screening potential for hypertension risk in children. This is similar to the findings in a recent study by Ma et $a l .{ }^{31}$, who demonstrated that WC and WSR were no better than BMI to identify the risk of hypertension in children. However, Liang et al. ${ }^{32}$ showed a similar discriminatory capacity of BMI, WC and WSR for hypertension risk.

The strong positive association between increasing BMI and elevated blood pressure might be due to the fact that obesity progressively raises blood pressure by changing cardiac output, cardiac systolic and diastolic function, renal pressure natriuresis ${ }^{33}$, sympathetic nervous system, reninangiotensin-aldosterone system activation ${ }^{34}$ and aortic stiffness ${ }^{35}$. However, the possible mechanism 
whereby obesity lead to higher blood pressure might be enhanced adipocyte secretion of adipokines and pro-inflammatory cytokines ${ }^{36}$. In a recent study, Pierce et al. found that adolescents with raised BMI had increased left ventricular mass, high aortic wave amplitude and SBP, compared with their peers with normal weight ${ }^{37}$. This might be the reason that BMI has been recommended as an index of adiposity for epidemiological studies / clinical practice ${ }^{38}$. Moreover, amount of visceral adipose tissue in young adults was also associated with BMI changes during adolescence ${ }^{39}$.

The cross-sectional design of our study allows us to demonstrate the associations between adiposity measures and blood pressure in children. Further studies with larger samples to determine a cut-off value of adiposity measures should be conducted. A limitation of the present study was unavailability of biochemical measurements so that it was not possible to examine the usefulness of these indices for screening other cardio-metabolic risk factors.

\section{Conclusions}

BMI had the highest odds ratio for hypertension, and was the best adiposity measure to assess hypertension.

\section{References}

1. Abdulle A, Al-Junaibi A, Nagelkerke N. High blood pressure and its association with body weight among children and adolescents in the United Arab Emirates. PLoS One 2014; 9(1): e85129.

https://doi.org/10.1371/journal.pone.0085 129

PMid: 24465493 PMCid: PMC3896369

2. World Health Organization. Obesity and overweight. Geneva: Fact Sheet No. 311; 2006.

3. Kajale NA, Khadilkar AV, Chiplonkar SA, Khadilkar VV. Body fat indices for identifying risk of hypertension in Indian children. Indian Pediatrics 2014; 51(7):555-60.

https://doi.org/10.1007/s13312-014-04464

PMid: 25031134

4. Badeli H, Hassankhani A, Naeemi Z, Hosseinzadeh S, Mehrabi S, Pourkarimi $\mathrm{M}$, et al. Prevalence of hypertension and obesity-related hypertension in urban school-aged children in Rasht. Iranian
Journal of Kidney Diseases 2016; 10 (6):364-8.

PMid: 27903995

5. Scorof J, Daniels S. Obesity hypertension in children: a problem of epidemic proportions. Hypertension 2002; 40 (4): 441-7.

https://doi.org/10.1161/01.HYP.00000329 40.33466 .12

6. Monyeki K, Kemper H, Mogale A, Hay L, Sekgala M, Mashiane T, et al. Association between blood pressure and birth weight among rural south African children: Ellisras longitudinal study. International Journal of Environmental Research and Public Health 2017; 14(9): Pii: E974. https://doi.org/10.3390/ijerph14090974

7. Chen B, Li H. Waist circumference as an indicator of high blood pressure in preschool obese children. Asia Pacific Journal of Clinical Nutrition 2011; 20 (4):557-62.

PMid: 22094841

8. Nkeh-Chungag BN, Sekokotla AM, Sewani-Rusike C, Namugowa A, Iputo JE. Prevalence of hypertension and prehypertension in 13-17 year old adolescents living in Mthatha - South Africa: a cross-sectional study. Central European Journal of Public Health 2015; 23 (1): 59-64.

https://doi.org/10.21101/cejph.a3922

PMid: 26036100

9. Munthali RJ, Kagura J, Lombard Z, Norris SA. Childhood adiposity trajectories are associated with late adolescent blood pressure: birth to twenty cohort. $B M C$ Public Health 2016; 16:665. https://doi.org/10.1186/s12889-016-3337$\mathrm{x}$

PMid: 27473865 PMCid: PMC4966706

10. Daniels SR, Pratt CA, Hayman LL. Reduction of risk for cardiovascular disease in children and adolescents. Circulation 2011; 124(15):1673-86. https://doi.org/10.1161/CIRCULATIONA HA. 110.016170

PMid: 21986774 PMCid: PMC3751579

11. Lurbe E, Alvarez V, Redon J, Obesity, body fat distribution and ambulatory 
blood pressure in children and adolescents. The Journal of Clinical Hypertension 2001; 3(6): 362-7. https://doi.org/10.1111/j.15246175.2001.0 0492.x

12. Arora S, Gupta S, Singh P. Assessment of risk factors for hypertension and obesity among adolescents. Sri Lanka Journal of Child Health 2017; 46: 48-54. https://doi.org/10.4038/sljch.v46i1.8120

13. Gamboa-Delgado EM, DominguezUrrego CL, Quintero-Lesmes DC. Waistto-height ratio and its relation with cardiometabolic risk factors in children from Bucaramanga, Colombia. Nutricion Hospitalaria 2017; 34(5):1338-44.

PMid: 29280649

14. Lohman TG, Roche AF, Martorell R. Anthropometric standardization reference manual. Illinois: Human Kinetic. 1988.

PMCid: PMC279682

15. National High Blood Pressure Working Programme. Working group on high blood pressure in children and adolescents: The fourth report on the diagnosis, evaluation and treatment of high blood pressure in children and adolescents. Pediatrics 2004; 114 (2): 555-76. https://doi.org/10.1542/peds.114.2.S2.555 PMid: 15286277

16. Balagopal PB, de Ferranti SD, Cook S, Daniels SR, Gidding SS, Hayman LL, et al. Nontraditional risk factors and biomarkers for cardiovascular disease: mechanistic, research, and clinical considerations for youth a scientific statement from the American Heart Association. Circulation 2011; 123(23): 2749-69.

https://doi.org/10.1161/CIR.0b013e31821

c7c64

PMid: 21555711

17. Riley M, Bluhm B. High blood pressure in children and adolescents. American Family Physician 2012; 85(7): 693-700. PMid: 22534345

18. Durrani AM, Waseem F. Blood pressure distribution and its relation to anthropometric measurements among school children in Aligarh. Indian Journal of Public Health 2011; 55(2):121-4. https://doi.org/10.4103/0019-557X.85246 PMid: 21941047

19. Hansen ML, Gunn PW, Kaelber DC. Under-diagnosis of hypertension in children and adolescents. Journal of the American Medical Association 2007; 298(8): 874-9.

https://doi.org/10.1001/jama.298.8.874

PMid: 17712071

20. Patel U, Patel NP, Jain S, Ratre BK, Shrivastava S. High blood pressure in school going adolescents: prevalence and risk factors: pediatric review: International Journal of Pediatric Research 2014; 1(1):3-9.

21. Vohra R, Bansal M, Grover N, Bhardwaj $\mathrm{P}$, Kumar P. Cardiovascular risk factors in adolescents with a family history of cardiovascular disease Sri Lanka Journal of Child Health, 2017; 46(4): 326-30.

22. Taksande A, Chaturvedi P, Vilhekar K, Jain M. Distribution of blood pressure in school going children in rural area of Wardha district, Maharashatra, India. Annals of Pediatric Cardiology 2008; 1(2):101-6. https://doi.org/10.4103/0974-2069.43874 PMid: 20300250 PMCid: PMC2840757

23. Kumar P, Kumar D, Ranjan A, Singh CM, Pandey S, Agarwal N. Prevalence of hypertension and its risk factors among school going adolescents of Patna, India. Journal of Clinical and Diagnostic Research 2017; 11(1): SC01-SC04. https://doi.org/10.7860/JCDR/2017/23886 .9196

24. Durrani AM, Waseem F. Blood pressure distribution and its relation to anthropometric measurements among school children in Aligarh. Indian Journal of Public Health 2011; 55(2):121-4. https://doi.org/10.4103/0019-557X.85246 PMid: 21941047

25. Zhang CX, Shi JD, Huang HY, Feng LM, Ma J. Nutritional status and its relationship with blood pressure among children and adolescents in South China. European Journal of Pediatrics 2012; 171(7):1073-79. 
https://doi.org/10.1007/s00431-012-1684-

$\mathrm{x}$

PMid: 22311167

26. Sun M, Zhou HY, Deng HZ. Study of the risk factors of blood pressure in children. Bulletin of Hunan Medical University 2000; 25(3):238-40.

PMid: 12212152

27. Omisore AG, Omisore B, Abioye-Kuteyi EA, Bello IS, Olowookere SA. In-school adolescents' weight status and blood pressure profile in South-western Nigeria: urban-rural comparison. $B M C$ Obesity 2018; 5:2.

https://doi.org/10.1186/s40608-018-01793

PMid: 29423239 PMCid: PMC5787246

28. Yang Y, Dong B, Wang S, Dong Y, Zou $\mathrm{Z}$, et al. Prevalence of high blood pressure subtypes and its associations with BMI in Chinese children: a national crosssectional survey. BMC Public Health 2017; 17(1):598.

https://doi.org/10.1186/s12889-017-45222

PMid: 28651555 PMCid: PMC5485696

29. Graf C, Rost SV, Koch B, Heinen S, Falkowski G, Dordel S, et al. Data from the StEP TWO programme showing the effect on blood pressure and different parameters for obesity in overweight and obese primary school children. Cardiology in the Young 2005; 15 (3):291-8. https://doi.org/10.1017/S10479511050005 94

PMid: 15865832

30. Falkner B, Gidding SS, Ramirez-Garnica G, Wiltrout SA, West D, Rappaport EB. The relationship of body mass index and blood pressure in primary care pediatric patients. Journal of Pediatrics 2006; 148 (2):195-200.

https://doi.org/10.1016/j.jpeds.2005.10.03 0

PMid: 16492428

31. Ma C, Wang R, Liu Y, Lu Q, Lu N, Tian $\mathrm{Y}$, et al. Performance of obesity indices for screening elevated blood pressure in pediatric population: systematic review and meta-analysis. Medicine 2016; 95(39):e4811.
https://doi.org/10.1097/MD.00000000000

04811

PMid: 27684808 PMCid: PMC5265901

32. Liang JJ, Chen YJ, Jin Y, Yang WH, Mai $\mathrm{JC}$, Ma J, et al. Comparison of adiposity measures in the identification of children with elevated blood pressure in Guangzhou, China. Journal of Human Hypertension 2015; 29(12):732-6. https://doi.org/10.1038/jhh.2015.16 PMid: 25787781

33. Hall JE, Brands MW, Henegar JR. Mechanisms of hypertension and kidney disease in obesity. Annals of the New York Academy of Sciences 1999; 892(1): 91107.

https://doi.org/10.1111/j.17496632.1999.t b07788.x

PMid: 10842655

34. Rahmouni K, Correia ML, Haynes WG, Mark AL. Obesity-associated hypertension new insights into mechanisms. Hypertension 2005; 45(1): 9-14.

https://doi.org/10.1161/01.HYP.00001513 25.83008.b4

PMid: 15583075

35. Wildman RP, Mackey RH, Bostom A, Thompson T, Sutton-Tyrrell K. Measures of obesity are associated with vascular stiffness in young and older adults. Hypertension 2003; 42(4):468-73. https://doi.org/10.1161/01.HYP.00000903 60.78539.CD

PMid: 12953016

36. Erlingsdottir A, Indridason OS, Thorvaldsson O, Edvardsson VO. Blood pressure in children and target-organ damage later in life. Pediatric Nephrology 2010; 25(2):323-8. https://doi.org/10.1007/s00467-009-13503

PMid: 19946710

37. Pierce GL, Pajaniappan M, DiPietro A, Darracott-Woei-A-Sack K, Kapuku GK. Abnormal central pulsatile haemodynamics in adolescents with obesity: higher aortic forward pressure wave amplitude is independently associated with greater left ventricular mass. Hypertension 2016; 68(5):1200-7. 
https://doi.org/10.1161/HYPERTENSION

AHA.116.07918

PMid: 27620396 PMCid: PMC5836470

38. Dietz WH, Bellizzi MC. Introduction: the use of body mass index to assess obesity in children. American Journal of Clinical Nutrition 1999; 70(1): 1235-55.

https://doi.org/10.1093/ajcn/70.1.123s

PMid: 10419414

39. Kindblom JM, Lorentzon M, Hellqvist A, Lonn L, Brandberg J, Nilsson S, et al. BMI changes during childhood and adolescence as predictors of amount of adult subcutaneous and visceral adipose tissue in men: the GOOD Study. Diabetes 2009; 58 (4): 867-74.

https://doi.org/10.2337/db08-0606

PMid: 19168597 PMCid: PMC2661578 